\title{
ANÁLISE EMPÍRICA DA FRAGILIDADE AMBIENTAL NA MICRORREGIÃO RIO VERMELHO (GO)
}

Resumo: A pesquisa teve como objetivo identificar níveis hierarquizados de fragilidade ambiental na Microrregião Geográfica Rio Vermelho (GO), como forma de subsidiar tomada de decisão e planejamento de uso sustentável dos recursos naturais. Para tanto, adotou-se a proposta metodológica de Ross (1994), com base nas variáveis ambientais de dissecção do relevo, pluviometria, classe de solo e uso e cobertura da terra. Foram utilizadas geotecnologias na determinação de informações de síntese referentes à Fragilidade Potencial e Fragilidade Emergente. Os resultados obtidos para a Fragilidade Potencial consistem em quatro classes hierarquizadas que são: muito baixa $(37,57 \%)$, seguida da classe média $(32,81 \%)$, baixa $(29,13 \%)$ e alta $(0,49 \%)$. Para a Fragilidade Emergente foram geradas três classes hierárquicas de fragilidade, predominando a classe baixa $(69,04 \%)$, seguido da classe média $(30,94 \%)$ e alta $(0,02 \%)$.

Palavras-chave: Geotecnologias. Fragilidade Potencial. Fragilidade Emergente. Paisagem.

\section{EMPIRICAL ANALYSIS OF ENVIRONMENTAL FRAGILITY IN THE RIO VERMELHO MICROREGION (GOIÁS STATE - BRAZIL)}

Abstract: The research aimed to identify hierarchical levels of environmental fragility in the Geographical Microregion Rio Vermelho (GO), to support decision-making and planning for the sustainable use of natural resources. For this purpose, the methodological proposal of Ross (1994) was adopted, using the variables of relief dissection, rainfall, soil class and land use and land cover. Geotechnologies were used to determine synthesis information regarding Potential and Emerging Fragility. The results for Potential Fragilty presented four hierarchical classes: very low class $(37.57 \%)$, medium class $(32.81 \%)$, low class $(29.13 \%)$ and high class $(0.49 \%)$. For Emerging Fragilty, three hierarchical frailty classes were generated, predominantly the low class $(69.04 \%)$, followed by the medium class $(30.94 \%)$ and high class $(0.02 \%)$.

Keywords: Geotechnologies. Potential Fragility. Emerging Fragility. Landscape.

\section{ANÁLISIS EMPÍRICO DE LA FRAGILIDAD AMBIENTAL EM LA MICRORREGIÓN RIO VERMELHO (ESTADO DE GOIÁS - BRASIL)}

Resumen: La investigación tuvo como objetivo identificar niveles jerárquicos de fragilidad ambiental en la Microrregión Geográfica Rio Vermelho (GO), para apoyar la toma de decisiones y la planificación para el uso sostenible de los recursos

\footnotetext{
${ }^{1}$ Universidade Federal de Jataí, Pós Graduação em Geografia, Jataí, Brasil, cleoniceregis@gmail.com, https://orcid.org/0000-0003-4115-9854

2 Universidade Federal de Jataí, Pós Graduação em Geografia, Jataí, Brasil, alecioperini@ufj.edu.br, https://orcid.org/0000-0002-4485-0336
} 
naturales. Para ello, se adoptó la propuesta metodológica de Ross (1994), utilizando las variables de disección del relieve, precipitación, clase de suelo y uso del suelo. Se utilizaron geotecnologías para determinar la información de síntesis con respecto a la fragilidad potencial y emergente. Los resultados de Fragilidad Potencial presentaron cuatro clases jerárquicas: muy bajo (37,57\%), promedio $(32,81 \%)$, bajo $(29,13 \%)$ y elevado $(0,49 \%)$. Para la fragilidad emergente, se generaron tres clases de fragilidad jerárquica, predominantemente la clase baja $(69,04 \%)$, promedio $(30,94 \%)$ y elevado $(0,02 \%)$.

Palabras clave: Geotecnologías. Fragilidad Potencial. Fragilidad Emergente. Paisaje.

\section{INTRODUÇÃO}

O modelo de apropriação do ambiente natural incentivado pelo processo de globalização de economias e impulsionado pela nova ordem econômica mundial tem demonstrado níveis cada vez mais elevados de exploração dos recursos naturais, intensificados pelo desenvolvimento das atividades econômicas, promovendo transformações do espaço, associadas à redução do espaço natural, e como consequência gerando impactos negativos no meio ambiente.

Estas transformações do espaço estão presentes na Microrregião Geográfica Rio Vermelho - GO (noroeste goiano), iniciando na década de 1990 e intensificando-se a partir do ano 2000, através do aumento considerável da atividade agrícola, principalmente agricultura irrigada por sistema de pivô central no segmento de commodities.

Outro fator importante é constatado a partir de 2010, consiste no aumento de forma expressiva das áreas para uso agrícola em regime de sequeiro, também voltada para o segmento de commodities.

Estas características evidenciam um novo momento no processo de uso e ocupação da terra na região que até então caracterizava-se pela atividade de pecuária. Ambas as atividades se destacam principalmente nos municípios de Aruanã, Britânia, Cidade de Goiás, Itapirapuã, Jussara, Matrinchã e Santa Fé de Goiás (SOARES, 2020)

A atividade pecuária é praticada em molde intensivo e subsidiada pela adoção de práticas de sistema de manejo baseado em alta tecnologia, garantindo maior produtividade por unidade de área em uso.

O investimento de capital na apropriação do meio natural na microrregião promoveu o desenvolvimento de uma agropecuária tecnificada, impulsionada por 
apresentar características edafoclimáticas e relevo favoráveis, imprimindo um novo arranjo na paisagem regional (SOARES, 2020).

Diante de tais aspectos, torna-se relevante a geração de base de dados e informação geográfica que subsidie a formulação de estratégias de planejamento, identificando no mosaico de paisagens as suas fragilidades e potencialidades sob a ótica da sustentabilidade.

Neste sentido, Ross (1994) apresenta suas propostas de metodologias de estudo de fragilidade ambiental voltados para elaboração de Análise Empírica da Fragilidade dos Ambientes Naturais e Antropizados, os quais fundamentam-se sob o prisma de que a natureza apresenta funcionalidade intrínseca entre seus componentes físicos e bióticos sob o conceito de Unidade Ecodinâmica preconizada por Tricart (1977).

A aplicação metodológica de Ross (1994), subsidia um diagnóstico reportando as relações de dependência e/ou sinergia entre os componentes físicos, bióticos e antrópicos. Buscando assim, compreender a estrutura e a dinâmica da região como forma de auxiliar o planejamento ambiental e gestão do território no sentido de criar instrumentos técnicos legais que possam nortear de forma sustentável a expansão de atividades econômicas.

Desta forma, a modelagem geográfica das informações multitemáticas possibilitará a geração de um prognóstico permitindo a espacialização de zonas com potencialidades e fragilidades para determinados tipos de uso. Partindo deste princípio é necessário ponderar quanto ao estudo da fragilidade ambiental no âmbito da fragilidade potencial e da fragilidade emergente.

A fragilidade potencial é conceituada como fragilidade natural de um ambiente pelos seus elementos físicos naturais, baseada na declividade, potencial erosivo das chuvas e classes de solo, já a fragilidade emergente além de considerar essas características físicas naturais, contempla também os diferentes graus de proteção das diferentes classes de uso da terra e cobertura vegetal (KAWAKUBO et al., 2005).

Para Ross (1994, p. 65), "os estudos integrados de um determinado território pressupõem o entendimento da dinâmica de funcionalidade do ambiente natural com ou sem as intervenções humanas". Neste contexto, os sistemas socioambientais apresentam-se em espaços geográficos estruturados em consequência do processo de uso e ocupação territorial espontânea ou planejada, de forma que os espaços 
naturais devem ser compreendidos e geridos considerando suas potencialidades e fragilidades ambientais (STORTO e COCATO, 2018).

Neste sentido, a produção de cartografia da fragilidade ambiental apoia-se na utilização de geotecnologias como subsídio para tomadas de decisões no que tange ao ordenamento territorial e gestão ambiental apresentando variadas potencialidades relacionadas diretamente à capacidade de aquisição, organização e análise de dados espaciais (FREITAS e SANTOS, 2014).

$\mathrm{Na}$ determinação dessas potencialidades dos recursos naturais Donha et al., (2006), afirmam ser necessário realizar estudos acerca dos elementos do meio natural, são eles: solos, relevo, geologia, água, clima e vegetação, os quais devem ser avaliados de maneira integrada na análise da fragilidade ambiental, considerando-se sempre as intervenções antrópicas modificadoras dos ambientes naturais.

Neste contexto, a pesquisa teve como objetivo a elaboração de informação de síntese a partir da identificação de níveis hierarquizados de Fragilidade Potencial e Fragilidade Emergente na Microrregião Geográfica Rio Vermelho - GO, utilizando geotecnologias na produção de informação geográfica como forma de subsidiar tomada de decisão e planejamento do uso sustentável dos recursos naturais.

\section{MATERIAL E MÉTODO}

\section{1 Área de Estudo}

A Microrregião Geográfica Rio Vermelho constitui-se numa divisão oficial do Instituto Brasileiro de Geografia e Estatística - IBGE, formada por 9 municípios localizados no centro-oeste goiano entre as coordenadas geográficas de

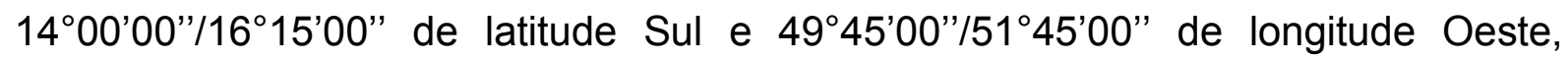
sendo eles: Araguapaz, Aruanã, Britânia, Faina, Goiás, Itapirapuã, Jussara, Matrinchã e Santa Fé de Goiás, apresentando área territorial total de $20.214,8$ km² (IBGE, 2016) e população total estimada em 86.408 habitantes em 2018 (IBGE, 2018) (Figura 01). 
Figura 01 - Mapa de localização da área de estudo.
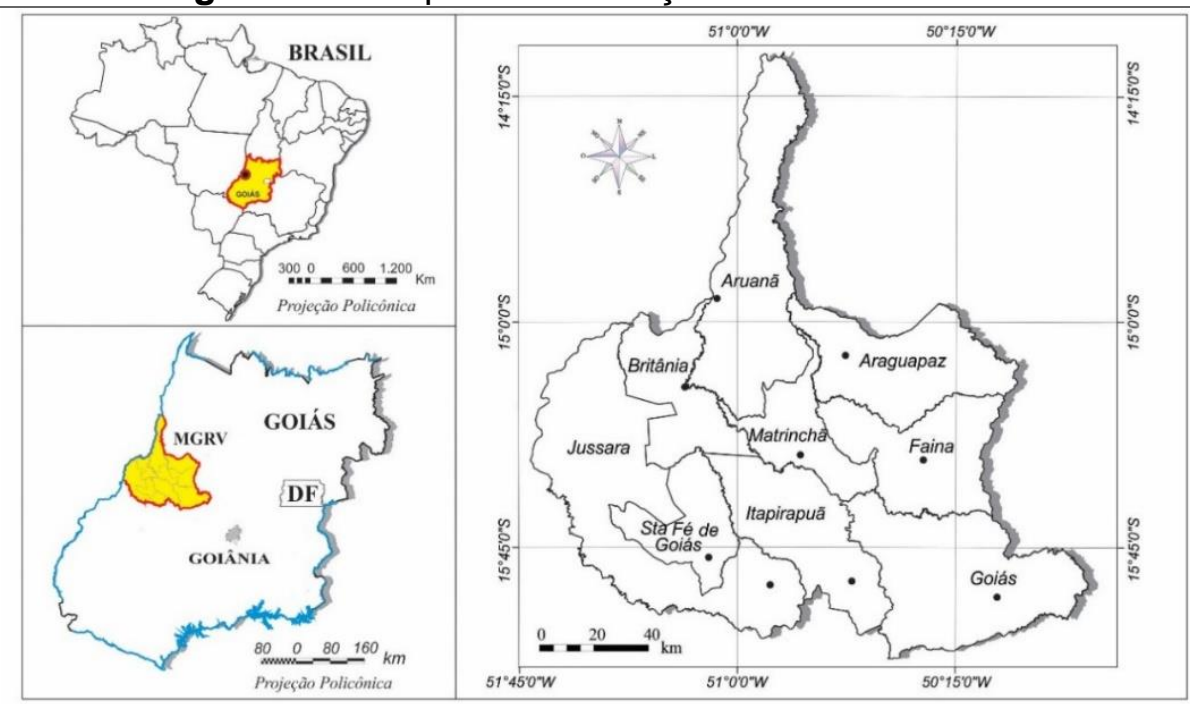

Fonte: Base Cartográfica Digital, IBGE, 2016; Elaboração: Autores, 2020.

\subsection{Materiais}

O presente estudo baseou-se em pesquisa bibliográfica acerca da proposta metodológica de Ross (1994) e adaptações de outros autores para mapeamento de fragilidade ambiental dos ambientes antropizados e em pesquisa documental para a estruturação de bases cartográficas para este mapeamento. Foram utilizados os seguintes materiais (Quadro 01):

Quadro 01- Materiais utilizados.

\begin{tabular}{|c|c|c|c|c|}
\hline Cód. & Informação & Material Utilizado & Escala/Resolução & Fonte \\
\hline 1 & $\begin{array}{l}\text { Estruturante } \\
\text { (mídia digital) }\end{array}$ & $\begin{array}{l}\text { Cartografia de Base } \\
\text { (limites administrativos, } \\
\text { hidrografia) }\end{array}$ & $1 / 100.000$ & $\begin{array}{l}\text { IBGE (2016) } \\
\quad \text { (SIEG) }\end{array}$ \\
\hline 2 & $\begin{array}{c}\text { Inventário } \\
\text { (mídia digital) }\end{array}$ & $\begin{array}{c}\text { LANDSAT-8 Sensor OLI } \\
(223 / 071,223 / 070,222 / 071)\end{array}$ & $\begin{array}{l}\text { resolução espacial } \\
15 / 30 \mathrm{~m}\end{array}$ & USGS (2018) \\
\hline 3 & $\begin{array}{c}\text { Suporte } \\
\text { (mídia digital) }\end{array}$ & Solo & $1 / 1.000 .000$ & $\begin{array}{l}\text { (Projeto RadamBrasil) } \\
\text { Agência Ambiental de } \\
\text { Goiás (2005) - (SIEG) }\end{array}$ \\
\hline 4 & $\begin{array}{l}\text { Suporte } \\
\text { (mídia digital) }\end{array}$ & Geologia & $1 / 500.000$ & $\begin{array}{l}\text { Superintendência de } \\
\text { Geologia e Mineração } \\
\text { (SIC) - } 2008 \text { - (SIEG) }\end{array}$ \\
\hline 5 & $\begin{array}{l}\text { Suporte } \\
\text { (mídia digital) }\end{array}$ & Geomorfologia & $1 / 500.000$ & $\begin{array}{l}\text { Superintendência de } \\
\text { Geologia e Mineração- } \\
\text { SIC (2006) - (SIEG) }\end{array}$ \\
\hline 6 & $\begin{array}{c}\text { Derivada } \\
\text { (mídia digital) }\end{array}$ & $\begin{array}{c}\text { Imagem Shuttle Radar } \\
\text { Topography Mission - SRTM } \\
\text { (Dissecação do relevo, } \\
\text { Hipsometria, Declividade) }\end{array}$ & $\begin{array}{l}\text { resolução espacial } \\
30 \mathrm{~m}\end{array}$ & USGS (2018) \\
\hline Cód. & Informação & Material Utilizado & Escala/Resolução & Fonte \\
\hline 7 & $\begin{array}{c}\text { Derivada } \\
\text { (mídia digital) }\end{array}$ & $\begin{array}{c}\text { Dados pluviométricos } \\
\text { Série Histórica de } 32 \text { anos } \\
(1985-2017)\end{array}$ & $\begin{array}{l}19 \text { postos } \\
\text { pluviométricos }\end{array}$ & $\begin{array}{c}\text { Rede } \\
\text { Hidrometeorológica } \\
\text { Nacional (RHN) - } \\
\text { Agência Nacional das } \\
\text { Águas (ANA) (2016) }\end{array}$ \\
\hline 8 & \multicolumn{4}{|c|}{ GPS de Navegação } \\
\hline 9 & \multirow{2}{*}{\multicolumn{4}{|c|}{$\begin{array}{l}\text { Software SPRING v.5.5.5® INPE (2018) - (Processamento Digital de Imagem) } \\
\text { Software ArcGIS v.10.6.1® ESRI (2018) - (Análise Espacial e Modelagem Geo }\end{array}$}} \\
\hline 10 & & & & \\
\hline
\end{tabular}




\subsection{Procedimentos Metodológicos}

A determinação das unidades de paisagem foi estruturada a partir da elaboração do mapeamento de diferentes variáveis geoambientais (geologia, geomorfologia, solos, relevo, uso da terra e cobertura vegetal) e aplicação de mecanismos de análise espacial e modelagem geográfica, implicando na sobreposição dos diferentes planos de informação utilizando o software ArcGIS v.10.6.1® (ESRI) fornecendo uma visão de síntese, instantânea e holística das paisagens.

A definição da fragilidade potencial (natural do ambiente) foi obtida a partir da confecção do mapa de solos e da produção de informação derivada de dissecação do relevo e pluviosidade provenientes dos dados cartográficos Imagem Shuttle Radar Topography Mission - SRTM e da série histórica dos índices pluviométricos, propiciando a sobreposição dessas variáveis ambientais em ambiente SIG. Para a produção cartográfica referente a fragilidade emergente foram processadas e cruzadas as camadas de informações em ambiente SIG das variáveis ambientais utilizadas na definição da fragilidade natural juntamente com a informação de uso da terra e cobertura vegetal obtido da interpretação das imagens Landsat 8 - sensor OLI.

A extração de dados/informações das imagens de satélite disponibilizada pelo USGS (2018) foi realizada por meio do processamento digital das imagens no software - SPRING® v.5.5.5 (INPE), sendo empregado a aplicação de um método de classificação supervisionado semiautomático através do processo de segmentação de imagem e pós-classificação pelo método de interpretação visual das imagens.

O algoritmo orientado a objeto foi aplicado, resultando a delimitação e extração de regiões, resultando no particionamento da imagem em regiões (conjunto de pixels contíguos e uniformes) denominada de imagem rotulada, a qual passou por um processo de conversão para o formato vetorial, constituído de linhas e polígonos, possibilitando efetuar a interpretação visual dos objetos na imagem.

Para a validação das informações do mapeamento temático - 2018 foram realizadas 2 etapas de trabalho de campo (cadastro de 121 pontos/GPS de Navegação) para verificação da eficácia temática e a elaboração de uma matriz de erro enquanto técnica estatística descritiva e o cálculo do índice kappa como técnica analítica de acordo com Congalton (1991). Para tanto, utilizou-se o método 
estatístico do Coeficiente Kappa de Cohen (COEHN, 1960), sendo obtido como resultado um nível de confiança dos dados da ordem de $94 \%$.

A produção destas informações cartográficas possibilitou estabelecer uma hierarquia de fragilidade em função do estado de equilíbrio ou desequilíbrio do ambiente, sistematizando a atribuição de diferentes pesos (importância) para cada classe que compõem a camada de informação. Os pesos variam entre 1 a 5 , e estes valores representam, respectivamente, o menor e o maior grau de fragilidade ambiental (ou seja, as fragilidades variam entre muito baixa, baixa, média, alta e muito alta).

Para o presente estudo adotou-se em função da escala de detalhamento, a proposta de Ross (1994), tomando como referência morfométrica a matriz dos Ìndices de Dissecação do Relevo com a utilização dos dados SRTM, pautando-se na relação da densidade da rede de drenagem, dimensão interfluvial média (planimetria) e o grau de entalhamento dos canais da rede de drenagem (altimetria) na definição das hierarquias de influência de muito baixa a muito alta apoiado em processamento de análise espacial em ambiente SIG. Assim, o mapeamento dos índices de dissecação do relevo foi classificado em 5 classes hierárquicas, como mostra o quadro 02.

Quadro 02- Dissecação do relevo na Microrregião Geográfica Rio Vermelho-GO.

\begin{tabular}{|l|c|}
\hline \multicolumn{1}{|c|}{ Dissecação } & Níveis Hierárquicos \\
\hline 11 & Muito Baixa (1) \\
\hline 212212 & Baixa (2) \\
\hline $31,32,13,23$ & Média (3) \\
\hline $41,42,43,44,14,24,34$ & Alta (4) \\
\hline $51,52,53,54,55,15,25,35,45$ & Muito Alta (5) \\
\hline
\end{tabular}

Fonte: Ross (1994).

O mapeamento da erosividade da chuva (fator $\mathrm{R}$ ) - que representa a capacidade que a chuva tem em erodir um determinado tipo de solo em detrimento da sua cobertura, foi calculado a partir da equação 1 estabelecida por Wischmeier e Smith (1978) e adaptato para as normas brasileiras por Lombardi e Moldenhauer (1977) apud Bertoni e Lombardi (1999).

$$
\begin{array}{ccl}
\text { El }_{30}=67,355\left(\mathrm{r}^{2} / \mathrm{P}\right)^{8} 5 & \text { El30 = média mensal do índice de erosividade, em } \\
\text { Onde: } & \text { MJ.mm/(ha.h); } \\
& \mathrm{R}=\text { médias mensais de pluviosidade em mm; } \\
& \mathrm{P}=\text { médias anuais de pluviosidade em } \mathrm{mm} .
\end{array}
$$

Assim, os valores de erosividade foram classificados em 5 classes adequando-se ao proposto por Carvalho (1994) e apresentado no quadro 03. Os resultados obtidos de erosividade a partir da aplicação desta metodologia são em $\mathrm{MJ} \mathrm{mm} \mathrm{ha-1} \mathrm{h}^{-1}$ ano-1 sistema 
métrico internacional, os quais foram convertidos para o sistema métrico decimal (ton.m.mm/ha.h.ano), dividindo os valores em megajoules por 9,81.

Quadro 03 - Classes de erosividade da chuva - média anual.

Fonte: Carvalho (1994).

\begin{tabular}{|c|c|}
\hline Erosividade (ton.m.mm/ha.h.ano) & Classes de Erosividade \\
\hline $\mathrm{R}<250$ & Muito Baixa (1) \\
\hline $250<\mathrm{R}<500$ & Baixa (2) \\
\hline $500<\mathrm{R}<750$ & Média (3) \\
\hline $750<\mathrm{R}<1000$ & Alta (4) \\
\hline $\mathrm{R}>1000$ & Muito Alta (5) \\
\hline
\end{tabular}

A produção da informação de erosividade que atua enquanto agente modificador dos processos de morfodinâmica foi subsidiada a partir do mapeamento dos dados de pluviosidade de 19 postos pluviométricos (série histórica: 1985-2017) - (ANA, 2016), distribuídos pela área de estudo e seu entorno. Os dados foram processados com 0 interpolador determinístico Inverse Distance Weighting - IDW, resultando na definição de 4 classes pluviométricas, conforme Quadro 04.

Quadro 04 - Níveis hierárquicos da pluviosidade na Microrregião Geográfica Rio Vermelho $-\mathrm{GO}$.

\begin{tabular}{|c|c|}
\hline Pluviosidade & Níveis Hierárquicos \\
\hline$<1400 \mathrm{~mm}$ & Baixa (2) \\
\hline $1400-1500 \mathrm{~mm}$ & Baixa (2) \\
\hline $1500-1600 \mathrm{~mm}$ & Média (3) \\
\hline$>1600 \mathrm{~mm}$ & Média (3) \\
\hline
\end{tabular}

Fonte: Adaptado de Ross apud Spörl (2001).

A informação referente às classes de solos passou por um processo de reclassificação com base no grau de fragilidade ambiental, metodologia proposta por Ross (1994), a qual leva-se em consideração características como: textura, estrutura, plasticidade, nível de coesão das partículas e profundidade/espessura dos horizontes superficiais e subsuperficiais, conforme apresentado no Quadro 05.

Quadro 05 - Graus de fragilidade dos solos na Microrregião Geográfica Rio Vermelho - GO.

\begin{tabular}{|c|c|}
\hline Tipos de Solos & Fragilidade \\
\hline Latossolos & Muito Baixa (1) \\
\hline Argissolos & Média (3) \\
\hline Cambissolos & Alta (4) \\
\hline Plintossolos & Alta (4) \\
\hline Gleissolos & Muito Alta (5) \\
\hline Neossolos & Muito Alta (5) \\
\hline
\end{tabular}

Fonte: Adaptado de Ross (1994).

Segundo Ross (1994, p. 67), tais características estão diretamente relacionadas com relevo, litologia, e clima, elementos motores da pedogênese, e fatores determinantes das características físicas e químicas dos solos. Com base na metodologia de Ross (1994) e Kawakubo (2005), determinou-se o parâmetro do grau de proteção aos solos em função do 
uso da terra e cobertura vegetal, sendo estabelecido assim, uma hierarquia de capacidade de proteção, conforme Quadro 06.

Por meio da sobreposição dos layers com informações planimétricas e altimétricas espacializadas (solos, pluviosidade (níveis de erodibilidade dos solos) e os níveis de dissecação do relevo) resultou na definição de padrões de fragilidade ambiental representados pelas Unidadades Ecodinâmicas Estáveis (Instabilidade Potencial).

Quadro 06 - Graus de proteção do uso e cobertura da terra na Microrregião Geográfica Rio Vermelho - GO.

\begin{tabular}{|c|c|}
\hline Classes & Grau de proteção \\
\hline Mineração & Muito Baixa (5) \\
\hline Agricultura Sequeiro/Irrigada & Baixa (4) \\
\hline Pastagem/Silvicultura & Média (3) \\
\hline $\begin{array}{c}\text { Massa de Água /Granja/Parque_SD/Urbano/Vegetação } \\
\text { Remanescente. }\end{array}$ & Alta (2) \\
\hline
\end{tabular}

Fonte: Adaptado de Ross (1994) e Kawakubo (2005).

Em seguida definiu-se os padrões das Unidades Ecodinâmicas Instáveis (Instabilidade Emergente), a partir da sobreposição dos layers de informação espacial de solos, dissecação do relevo, pluviosidade (fragilidade natural) e o uso da terra e cobertura vegetal, considerando informações relativas às práticas conservacionistas (Fragilidade Emergente).

\section{RESULTADOS E DISCUSSÃO}

\subsection{Unidades de Paisagem na Microrregião Geográfica Rio Vermelho - GO}

Baseada na análise integrada do meio ambiente sob a ótica sistêmica, foi possível realizar uma análise conjunta destas variáveis ambientais na Microrregião Geográfica Rio Vermelho - GO, levando à compreensão de um sistema integrado e funcional com elementos que se encontram dinamicamente indissociáveis partindo da ideia do todo (Figura 02).

A produção de cartografia de síntese representa unidades espaciais que significam agrupamentos de lugares caracterizados por agrupamentos de atributos e se coloca como fator de grande relevância subsidiando metodologias para pesquisas. A partir dessa análise conjunta foram estabelecidas representações cartográficas compondo cinco (5) unidades paisagísticas:

1) Planície Fluvial (1179,97 km²/5,84\%): esta unidade de paisagem caracteriza-se por suas unidades funcionais, não funcionais e faixa aluvial atual (SIC, 2006), onde se tem a presença de vegetação do tipo contato na forma de encraves e/ou enclaves e floresta estacional semidecidual. A planície aluvial no trecho compreendido ao médio rio Araguaia apresenta 
um mosaico de unidades morfo-sedimentares datadas do Holoceno. Latrubesse e Carvalho (2006), destacam três unidades geomorfológicas: Planície de Inundação de Escoamento Impedido, Planície Fluvial com Espiras de Meandro (unidade dominada por paleomeandros) e Planície fluvial com bancos de areia. De acordo com o levantamento geomorfológico realizado por Latrubesse e Carvalho (2006), a Microrregião Geográfica Rio Vermelho apresenta Planícies Fluviais funcionais com padrão de meandriformes (PFm), em que os elementos geomorfológicos dominantes são os meandros. Nos locais onde predominam as espiras de meandros e paleomeandros são denominados de Planície Fluvial de Espiras de Meandro (PFem). Nas localidades com domínio da acreção de bancos de areia, tem -se a Planície Fluvial de Bancos Acrescidos (PFba) e nos locais onde não apresentam formas definidas são classificadas como Planície de Escoamento Impedido (PFei). 
Figura 02 - Unidades de Paisagem - Microrregião Geográfica Rio Vermelho - GO.

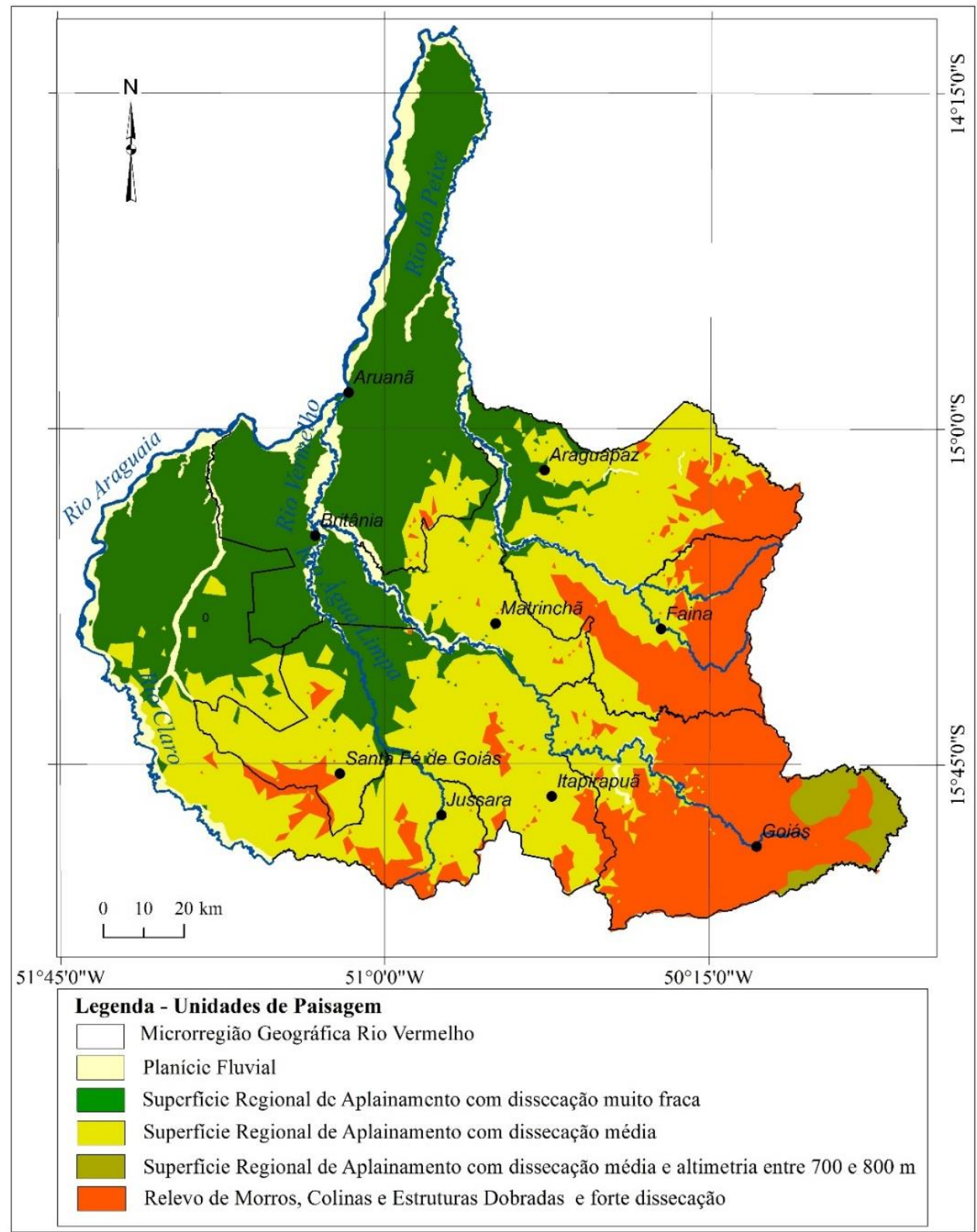

Metadados: Sistema de Projeção UTM - Datum: WGS-84; Fonte: Dados Geoambientais: Imagem SRTM/USGS-IMG-SEGPLAN (2017); Projeto RADAMBRASIL e Agência Ambiental de Goiás (2005); Superintendência de Geologia e Mineração-SIC (2006 e 2008); Elaboração: Soares, 2020.

Afluentes do rio Araguaia como o rio do Peixe, rio Vermelho e rio Claro, constituem em planícies fluviais bem desenvolvidas com diferentes unidades caracterizada por rochas pré-cambrianas. Segundo Latrubesse e Carvalho (2006), estes afluentes se caracterizam por apresentarem formas associadas ao padrão meandriforme, tais como, espiras de meandros e meandros abandonados formando lagos oxbow.

2) Superfície Regional de Aplainamento com dissecação muito baixa $(6755,28$ $\left.\mathrm{km}^{2} / 33,42 \%\right)$ : está localizada preferencialmente em área de fragilidade ambiental classificada como muito baixa e baixa. É desenvolvida sobre rochas 
pré-cambrianas com sistemas lacustres associado (tem associação com lagos da planície fluvial do rio Araguaia). Segundo informações da SIC (2006), é uma unidade composta por rochas do pré-cambriano com geração de relevos muito aplainados, cota altimétrica entre 250 e 400 m e níveis de lateritas bem desenvolvidos. Esta unidade paisagística apresenta grandes propriedades com pastagens de uso intensivo e do avanço nos últimos anos da agricultura irrigada e de sequeiro sobre Latossolos, Argissolos e Neossolos com textura variando entre argilosa, argilosa e média, média e argilosa, média e média argilosa/arenosa. Dados contidos no Diagnóstico Ambiental do Alto Araguaia (DIARA) realizado no âmbito do projeto de Macrozoneamento Agroecológico e Econômico do Estado de Goiás - Macrozae (2014), tem-se a presença de vegetação do tipo Savana Arborizada no extremo norte e sudoeste do município de Aruanã e uma faixa no norte/oeste do município de Jussara, caracterizada por solo com textura mais arenosa, abrigando inclusive área ambiental classificada como prioritária para conservação. Contato na forma de encraves aparece de forma expressiva em Aruanã, Britânia e norte/leste de Jussara. A Savana Parque ocupa uma faixa no sentido N/S de Aruanã, assim como a Savana Florestada no extremo sudeste deste mesmo município

3) Superfície Regional de Aplainamento com dissecação média (7516,04 $\mathrm{km} 2 / 37,18 \%$ ): apresenta desenvolvimento sobre rochas pré-cambrianas níveis de lateritas bem desenvolvidos entre 300 e $400 \mathrm{~m}$ de altitude em relevo plano e suave ondulado na Microrregião Geográfica Rio Vermelho. Possui solos do tipo Latossolos, Argissolos e Cambissolos com textura variando entre argilosa (Bacia do Paraná - sul de Jussara), média e argilosa, média predominando no oeste dos municípios de Faina e Araguapaz nas áreas de Cambissolos e média/cascalheira/argilosa cascalheira presente no centro/sul do município de Itapirapuã. Em relação a vegetação, os estudos de mapeamento do Macrozae (2014), mostram a presença de Contato na forma de encraves, Savana Arborizada e Savana Florestada.

4) Superfície regional de aplainamento com dissecação média e altimetria entre 700 e $800 \mathrm{~m}$ (352,36 km²/1,74\%): desenvolvida sobre rochas pré-cambrianas. Está compreendida no extremo leste do município de Goiás, apresentando relevo plano e suave ondulado e solo Latossolo com textura argilosa o que explica seu uso intensivo para atividade agrícola e vegetação classificada como Savana Arborizada. 
5) Relevo de morros, colinas e estruturas dobradas com forte dissecação (4.411,16 km²/5,84\%): são morfologias de relevo mais acidentado com cotas altimétricas variando entre 400 a $1.070 \mathrm{~m}$. Seu relevo de modelado convexo é classificado como ondulado, fortemente ondulado e montanhoso em terrenos cristalinos do complexo granito-gnáissico, apresentando fragilidade ambiental variando de média a alta. Nesta unidade predominam os solos Cambissolos entremeado por manchas de Argissolos e Neossolos Litólicos com textura variando de média/cascalhenta e argilosa/cascalhenta, predominando a atividade de pecuária nesta área. De acordo com o Macrozae (2014), a vegetação de Savana Arborizada e Contato na forma de encraves dominam a paisagem no meio de um mosaico de pastagens.

\subsection{A informação geográfica na definição da Fragilidade Potencial e Fragilidade Emergente na Microrregião Geográfica Rio Vermelho - GO}

As últimas décadas têm sido marcadas por preocupações da sociedade, relativas às grandes mudanças socioeconômicas e ambientais, associadas a modelos de apropriação, promovendo processos de degradação ambiental e práticas ambientais não sustentáveis. Neste contexto, o planejamento territorial assume grande relevância na definição de estratégias de gestão, necessitando ser subsidiado por análise de informações geográficas.

Seguindo a metodologia proposta, foi feito o levantamento e elaboração de informações sobre: relevo, solo, pluviometria, uso da terra e cobertura vegetal, sendo posteriormente, essas variáveis sobrepostas em software SIG e analisadas de forma integrada, gerando um produto síntese expressando os diferentes graus de fragilidade ambiental em função de suas características genéticas e pela interferência do homem no ambiente.

O mapeamento foi sistematizado mediante uma hierarquia de fragilidade do meio natural indicando estado de equilíbrio e desequilíbrio representada por: muito baixa (1), baixa (2), média (3), alta (4) e muito alta (5). O nível de fragilidade para a pluviometria ficou classificada em baixa, $52,26 \%$ e média com $37,74 \%$. A combinação desses algarismos propiciou hierarquizar os diferentes graus de fragilidade natural (Figuras 03 e 04). 


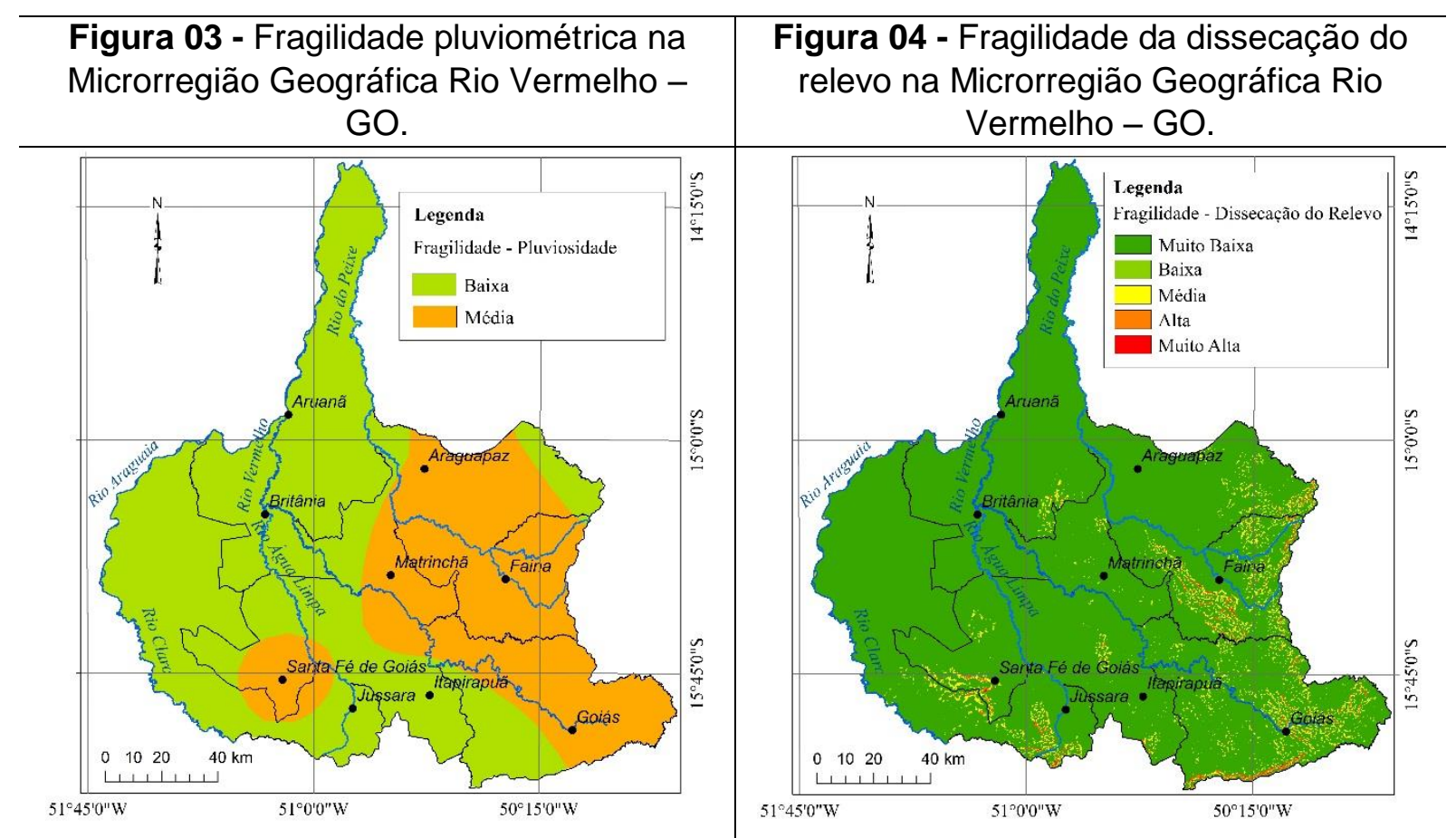

Metadados: Sistema de Projeção UTM - Datum: WGS-84; Fonte: 1- Postos Pluviométricos, ANA (2019); 2- Imagem SRTM/USGS; IMG; SEGPLAN, 2017; Elaboração: Soares, 2020.

Massa e Ross (2012), destacam a importância da variável precipitação na construção do modelo, na medida em que estas exercem ação direta na dinâmica do sistema ambiental. A distribuição dos dados de precipitações regula o regime hídrico, exercendo influência direta na evolução das formas do relevo por meio do intemperismo e erosão, principalmente pluvial e fluvial.

Com base na informação de fragilidade pluviométrica (Figura 03) (importante variável na correlação da capacidade da chuva em erodir o solo), foi calculado o valor de erosividade sendo obtido 507,4571 t ha-1 $\mathrm{ano}^{-1}$, classificado de acordo com a proposta de Carvalho (1994), como uma região de nível médio, valor este muito próximo do limiar de $250<\mathrm{R}<500$ classificados como baixa, apresentando condições favoráveis à capacidade de erosão dos solos na microrregião Rio Vermelho - GO.

Os dados de pluviosidade analisados na microrregião (índices pluviométricos variando entre $1.300 \mathrm{~mm}$ a $1.700 \mathrm{~mm}$, distribuídas entre os meses de outubro a março), apresentam sazonalidade pluviométrica característica da região de Cerrado, concentrando chuvas no verão e período seco no inverno, caracterizando seu ritmo hidrológico.

No período de estiagem no Cerrado, assim como na Microrregião Geográfica Rio Vermelho - GO, a escassez de chuvas acarreta a atuação menos expressiva 
dos processos de morfogênese. Porém, tem-se a ocorrência das chamadas primeiras chuvas, consistindo em chuvas torrenciais que ocorrem normalmente no mês de setembro, antecedendo o período chuvoso provocando processos expressivos de erosão (SOARES, 2020).

Isto acontece em função da menor proteção do solo em relação a uma cobertura vegetal de menor densidade e seu alto nível de ressecamento, e as áreas agrícolas em fase de preparação do solo para o plantio da safra que se encontram totalmente em estado de solo exposto, aumentando seu nível de fragilidade ambiental (SOARES, 2020).

Spörl (2001) ressalta a importância da distribuição sazonal das chuvas na determinação de perdas de solos em áreas agrícolas. As informações pluviométricas exercem ação direta na dinâmica do sistema ambiental, pois a forma de distribuição das precipitações regula o regime hídrico e exerce influência direta na evolução das formas de relevo através de intemperismo e erosão pluvial e fluvial (MASSA e ROSS, 2012).

O mapeamento de dissecação do relevo apresenta cinco graus de fragilidade a partir da estruturação da matriz de índices de dissecação que são as categorias de influência muito baixa ocupando 19.082, $28 \mathrm{~km}^{2}(94,40 \%)$, seguida de baixa com $741,57 \mathrm{~km}^{2}(3,67 \%)$, média $301,81 \mathrm{~km}^{2}(1,49 \%)$, alta $80,14 \mathrm{~km}^{2}(0,40 \%)$, e muito alta com $9,01 \mathrm{~km}^{2}(0,04 \%)$.

A dissecação muito baixa predomina na região consiste em áreas com altitude mais baixas, relevo plano e suavemente ondulado, solos com níveis maiores de argila e menores índices de susceptibilidade natural a processos erosivos, níveis de pluviometria mais baixo e mediano para o padrão local, sendo classificadas por Latrubesse e Carvalho (2006), de superfícies regionais de aplainamento.

Estas características formam um conjunto de "variáveis mais favoráveis", não descartando a necessidade da adoção de sistemas de manejo em função de suas limitações de uso dessas áreas de forma a reduzir os impactos negativos.

Por outro lado, tem-se um conjunto de "variáveis mais desfavoráveis" nas áreas de relevo ondulado e forte ondulado e com alto nível de dissecação do relevo, solos de textura mais frágeis e com maior susceptibilidade a processos erosivos, concentra os valores mais altos de pluviometria, tendo sua situação agravada quando detectado áreas com ausência de cobertura vegetal.

As classes mapeadas de dissecação alta e muito alta, são áreas que apresentam relevo classificados de acordo com a Superintendência de Geologia e 
Mineração - SIC (2006), como morros, colinas, estruturas dobradas, forte controle estrutural, apresentando características como: presença de vales encaixados, dimensão interfluvial pequena e apresenta maiores declividades.

O índice de dissecação do relevo é maior em áreas com características de vales encaixados, profundos e declividades acentuadas. Por outro lado, esta dissecação vai ser menor em áreas com relevo plano normalmente com baixa densidade de drenagem (GUIMARAES et al., 2017).

$\mathrm{Na}$ definição das diferentes categorias de fragilidade dos solos, levou-se em consideração as características de: textura, estrutura, porosidade, permeabilidade, profundidade e pedregosidade. Estas características constituem-se em importantes elementos que vão caracterizar o grau de desenvolvimento do solo e dimensionar seu nível de susceptibilidade a processos de degradação.

Estes elementos constituem em importantes componentes na determinação das classes de fragilidade, tais como: muito baixa ocupando $9.908,01 \mathrm{~km}^{2}(49,01 \%)$ constituída pelos Latossolos, média com 1.671,37 km² $(8,27 \%)$ em áreas de Argissolos, a classe alta ocupando $5.971,43 \mathrm{~km}^{2}(29,54 \%)$ em solos do tipo Cambissolos e muito alta com área equivalente a $2.664 \mathrm{~km}^{2}(13,18 \%)$, constituídas de solos do tipo Neossolos Quartzarênicos e Neossolos Litólicos (Figuras 05).

As zonas classificadas com fragilidade alta e muito alta representam área territorial considerável, juntamente com grande preocupação relativa aos problemas de manejo agrícola praticados com as atividades de agropecuária sobre tipos de solos (Neossolos, Cambissolos, Plintossolos e Gleissolos) mais frágeis naturalmente e com menor aptidão agrícola, tornando-os vulneráveis a processos de degradação ambiental.

A utilização de áreas com solo arenoso para plantio, em especial a soja, como ocorre em Neossolos localizados no município de Aruanã é uma preocupação, pois os nutrientes lixiviam-se muito rapidamente podendo atingir o lençol freático e provocar um desequilíbrio químico nestas áreas.

Já as áreas classificadas com fragilidade muito baixa ocupam toda a faixa oeste da microrregião, área denominada de Bacia do Bananal (SIC, 2008), com a presença de solos do tipo Latossolos e possui as seguintes características: são solos com avançado estágio de intemperização, muito desenvolvidos, apresentam mediana a baixa susceptibilidade a processos erosivos, são solos profundos e possuem baixo nível de fertilidade natural, uma limitação quanto ao uso agrícola, mas passível de ser resolvido a partir de sistemas de correção solo. 
Colaborando com os resultados obtidos Duarte et al., (2014), afirmam que as áreas onde se tem o predomínio de Latossolos, apresenta em sua maioria baixa declividade e acarretam uma fragilidade considerada baixa. Por outro lado, as áreas de solo da categoria Cambissolos apresentam declividades acentuadas, podem ser classificadas como de fragilidades altas, pois são fatores que estão estreitamente relacionados às características intrínsecas de cada um dos tipos de solo encontrados no local.

Quanto a definição do grau de proteção do uso e cobertura da terra, foram identificadas no processo de interpretação as classes de uso: Agricultura Sequeiro; Massa de Água Artificial; Massa de Água Natural; Granja; Mineração; Parque (SD); Pastagem; Pivô Central; Silvicultura; Urbano; Vegetação Remanescente, sendo estabelecido com base nos critérios da proposta de Ross (1994) (Figuras 06).

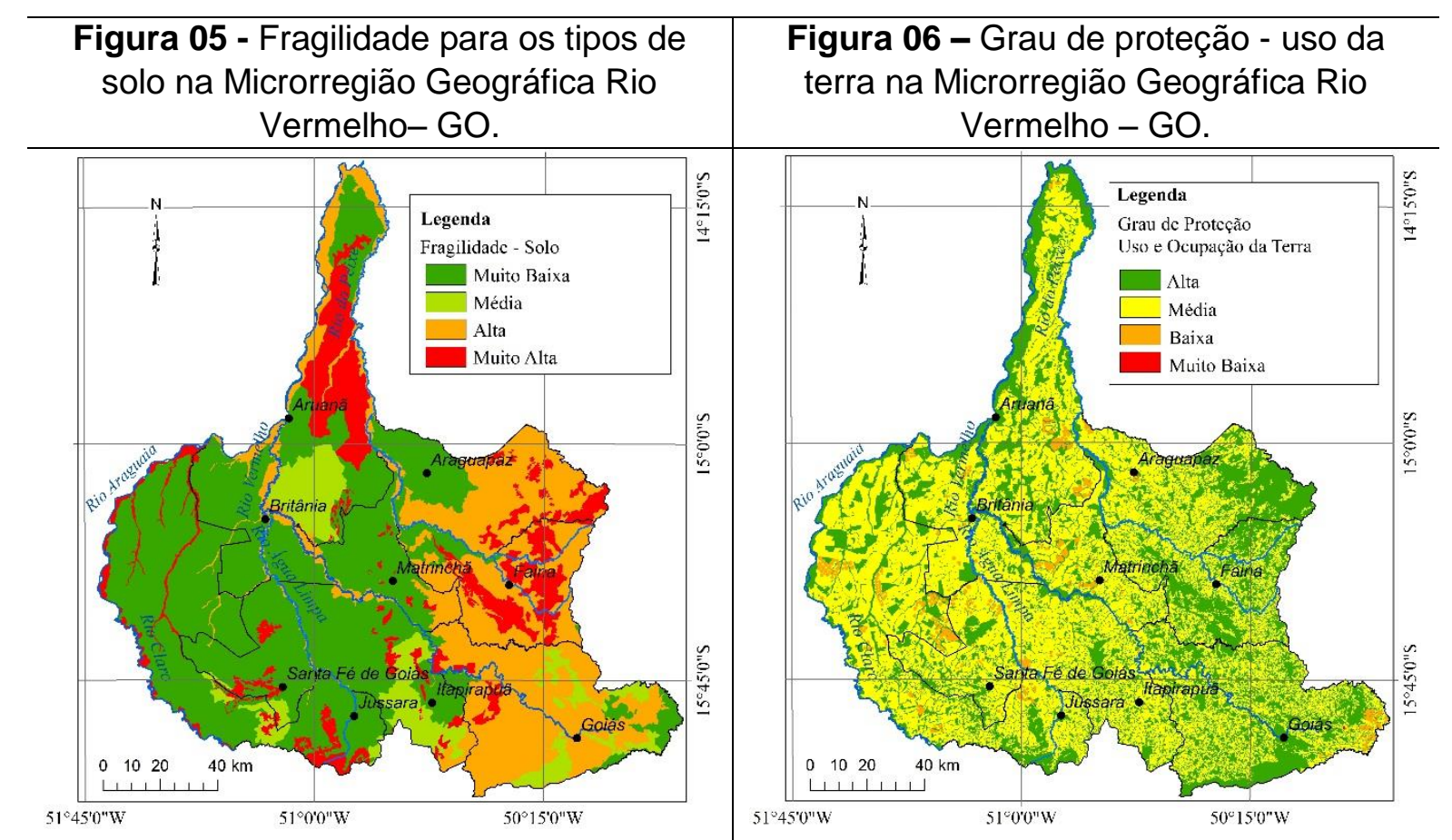

Metadados: Sistema de Projeção UTM - Datum: WGS-84; Fontes: 1- Projeto RADAMBRASIL, Agência Ambiental de Goiás (2005); 2- Imagem Landsat 8 OLI (2018); Elaboração: Soares, 2020.

$\mathrm{Na}$ hierarquização da capacidade de proteção dos solos, foram obtidas 4 classes, sendo: i) Muito Baixa com 0,75 km² (0,004 \%); ii) Baixa com 476,4 km² (2,36 $\%$ ) correspondendo as áreas de agricultura (irrigada e sequeiro); iii) Média ocupando expressiva área com $11.788,12 \mathrm{~km}^{2}(58,31 \%)$ constituem nas pastagens e na silvicultura; iv) Alta: ocupando $7.949,54 \mathrm{~km}^{2}(39,33 \%)$ correspondendo às áreas com cobertura vegetal, urbano, granja e os corpos de água 
As áreas com cobertura vegetal proporcionam proteção ao impacto das chuvas no solo da ação erosiva, mantendo-os em situação estável. A partir da combinação das diferentes variáveis (erosividade, dissecação do relevo, solo), resultou no mapeamento cartográfico de síntese com a definição de diferentes níveis hierárquicos de fragilidade natural do ambiente em função de suas carcterísticas genéticas para a Microrregião Geográfica Rio Vermelho em 2018 (Figura 07).

Figura 07 - Fragilidade potencial na Microrregião Geográfica Rio Vermelho - GO.

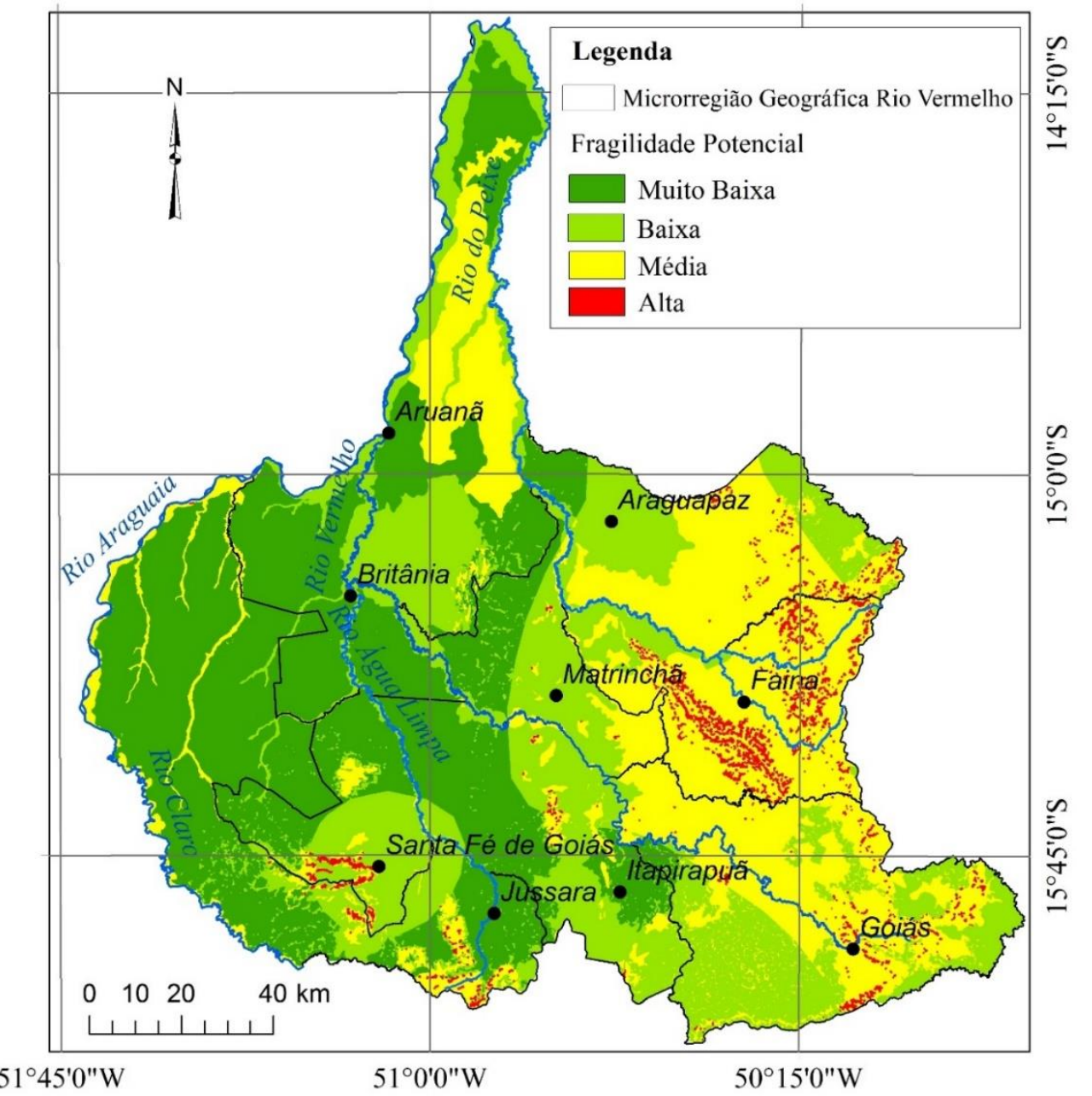

Metadados: Sistema de Projeção UTM - Datum: WGS-84; Fonte: Dados dos Postos Pluviométricos - ANA; Projeto RADAMBRASIL, Agência Ambiental de Goiás (2005); Elaboração: Autores, 2020.

Com base na metodologia de Ross (1994), foram determinadas 4 (quatro) classes hierárquicas de fragilidade potencial, conforme Tabela 02. Os dados apresentam predominância das classes: i) Muito Baixa (37,57\%), abrange área significativa da extensão ocidental da microrregião, é uma área de solos intemperizados, profundos e bem drenados e relevo plano; ii) Baixa $(29,13 \%)$ predominando em solos do tipo Argissolos; iii) Média (32,81\%) onde estão localizados os solos do tipo Cambissolos e Neossolos requerendo uma atenção especial por se tratar de solos que apresentam teores significativos de areia, o que 
os tornam naturalmente mais frágeis; iv) Alta (0,49\%) é decorrente da inclinação do terreno, está presente em áreas de relevo acidentado, estruturas dobradas, morros e colinas com alto controle estrutural.

As classes com fragilidade potencial muito baixa e baixa juntas somam $66,7 \%$ da área caracterizando um ambiente de relevo plano e suave ondulado recoberto por Latossolos e Argissolos, onde não são observados processos de morfogênese, consistindo em áreas de ocorrência do movimento de expansão da atividade agrícola mecanizada.

As classes definidas como média e alta do modelo de fragilidade potencial elaborado proporciona a leitura de um conjunto de variáveis associadas, reunindo fatores de potencialidade a erosividade pela chuva, relevo com grandes declives e dissecação, e ainda solos que apresentam fragilidades ao serem submetidos a determinados usos.

Tabela 02 - Classes de Fragilidade Potencial na Microrregião Geográfica Rio Vermelho -

\begin{tabular}{c|c|c}
\hline GO. & Area_km $\mathbf{k m}^{\mathbf{2}}$ & $\mathbf{( \% )}$ \\
\hline Classes & 7594,056 & 37,57 \\
\hline Muito Baixa & 5888,996 & 29,132 \\
\hline Baixa & 6633,376 & 32,814 \\
\hline Média & 98,378 & 0,487 \\
\hline Alta & 20214,81 & 100 \\
\hline Total
\end{tabular}

Fonte: Autores, 2020.

Estes resultados para a fragilidade potencial mostram que a Microrregião Geográfica Rio Vermelho apresenta um potencial à utilização significativo, sendo passível de discussão a sua potencialidade para atividades agrícolas e de outras atividades a serem implementadas.

A região apresenta extensa área com nível de fragilidade significativo, o que requer cautela, quanto aos tipos de atividades antrópicas, como por exemplo a constatação de atividade agrícola em área com fragilidade média, com solos mais arenosos e frágeis localizadas no município de Aruanã.

Para Ross (1994), é importante ressaltar que aliado a estes processos naturais, é cada vez mais significativa a ação humana, uma vez que "ao se apropriar do território e de seus recursos naturais, causa grandes alterações na paisagem natural com um ritmo muito mais intenso que aquele que normalmente a natureza imprime".

A combinação do modelo de fragilidade potencial com a variável antrópica (uso e cobertura da terra, resultou na definição da fragilidade emergente, a qual está associada aos diferentes graus de proteção em função dos diferentes tipos de uso 
da terra e cobertura vegetal na Microrregião Geográfica Rio Vermelho em 2018 (Figura 08) e (Tabela 03).

Figura 08 - Fragilidade ambiental emergente na Microrregião Geográfica Rio Vermelho GO.

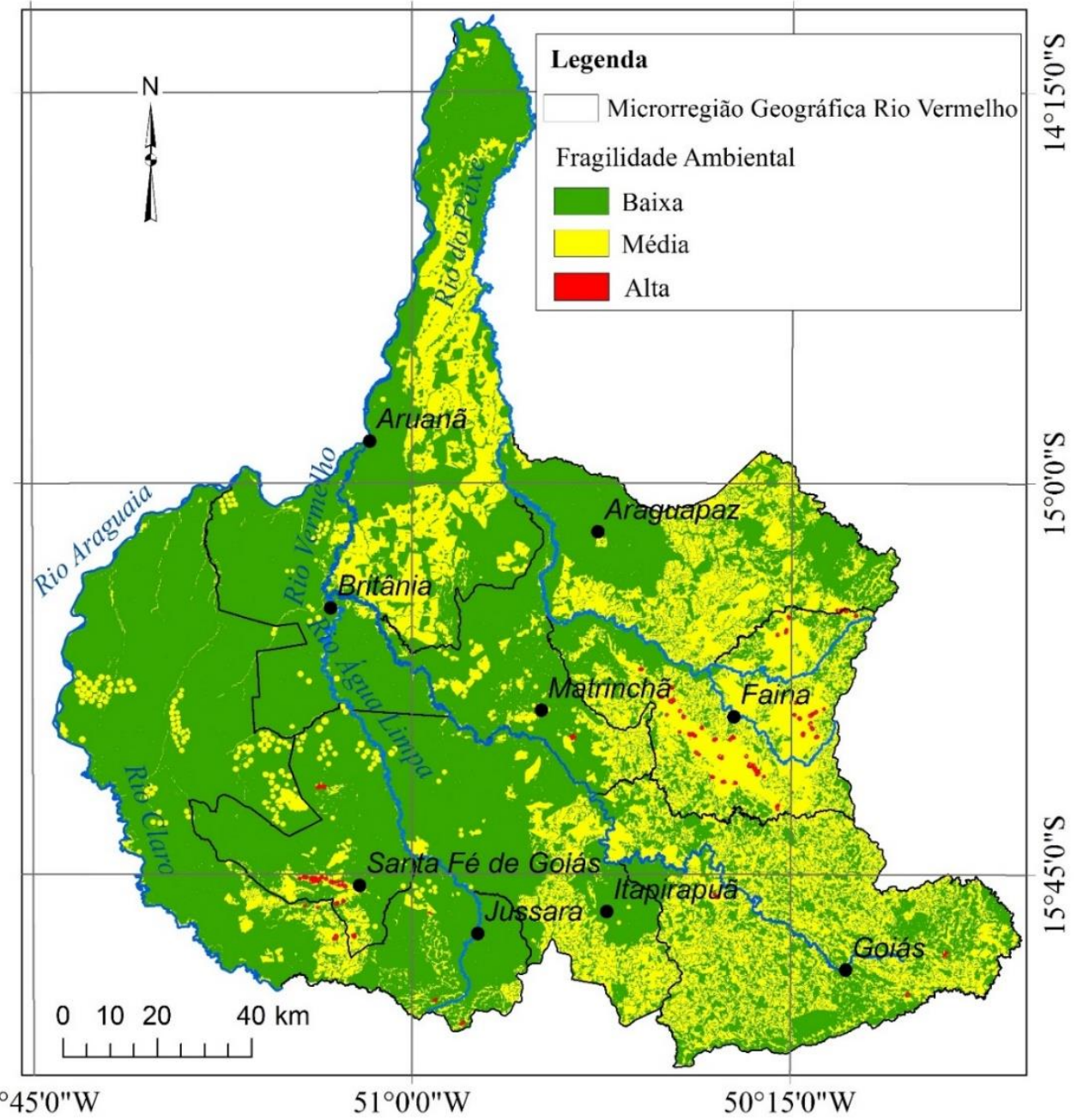

Metadados: Sistema de Projeção UTM - Datum: WGS-84; Fonte: Dados dos Postos Pluviométricos - ANA; Projeto RADAMBRASIL, Agência Ambiental de Goiás (2005); Imagem Landsat 8 OLI (2018); Elaboração: Autores, 2020.

A aplicação do modelo para fragilidade ambiental emergente na microrregião propiciou a geração de 3 (três) classes hierárquicas de fragilidade, predominando a classe Baixa ocupando (69,04\%), seguido da classe Média (30,94\%) e Alta $(0,02$ $\%)$, característico das áreas onde o relevo é acidentado, apresentando declives acentuados e forte controle estrutural.

Observa-se que no processo de modelagem geográfica, a classe obtida de fragilidade emergente é formada praticamente pela junção das áreas das classes muito baixa e baixa da fragilidade potencial. Esse aspecto demonstra que mesmo com o uso intenso por pastagens não altera significativamente a fragilidade do ambiente. 
Isto é devido ao fato de o peso da fragilidade para pastagens ser médio em função do seu grau de proteção, diferente da agricultura que tem classificação de peso como baixa proteção, indicando que com o processo de conversão das áreas de pastagem em áreas agrícolas há uma tendência que parte desse percentual se torne em área de fragilidade média, gerando uma maior intensidade da situação de alteração do equilíbrio dinâmico.

Tabela 03 - Classes de Fragilidade Emergente na Microrregião Geográfica Rio Vermelho GO.

\begin{tabular}{c|c|c}
\hline Classes & Area_km $\mathbf{k m}^{\mathbf{2}}$ & $(\%)$ \\
\hline Baixa & 13955,449 & 69,04 \\
\hline Média & 6254,637 & 30,94 \\
\hline Alta & 4,724 & 0,02 \\
\hline Total & 20214,81 & 100 \\
\hline
\end{tabular}

Fonte: Autores, 2020.

Tais aspectos mostram que a geração desta informação síntese permite dimensionar como os diferentes tipos de uso influenciam nos processos de desequilíbrios sobre o meio natural, deixando evidente a importância da produção deste tipo de geoinformação e seu monitoramento como subsídio ao manejo dos recursos naturais.

Diante desse quadro, observa-se que a Microrregião Geográfica Rio Vermelho - GO passou por um intenso processo de desmatamento de sua cobertura vegetal natural para dar lugar preferencialmente às pastagens. De acordo com os dados produzidos por Soares (2020) com a utilização de sensoriamento remoto, evidencia-se a conversão de áreas de remanescentes de vegetação em pastagem, com 675,44 km² de área desmatada entre 2000 e 2010 e 276,31 km² entre 2010 e 2018 em levantamento realizado.

De acordo com as informações do Cadastro Ambiental Rural (CAR) e disponibilizadas pelo Sistema Nacional de Cadastro Ambiental Rural ${ }^{3}$ (SICAR) (2019), as áreas destinadas para proteção ambiental em conformidade com o Código Florestal Brasileiro na microrregião Rio Vermelho apresentam: i) Área de Preservação Permanente (APP) com 2.041,23 km² (10,10\%), porém deste total $154,19 \mathrm{~km}^{2}$ necessitam serem recompostas devido à ações de desmatamentos e usos conflitivos com a legislação ambiental vigente; ii) Reserva Legal (averbada)

3 O Sistema Nacional de Cadastro Ambiental Rural - SICAR foi criado por meio do Decreto $\mathrm{n}^{\circ}$ 7.830/2012 e definido como sistema eletrônico de âmbito nacional destinado à integração e ao gerenciamento de informações ambientais dos imóveis rurais de todo o País. Essas informações destinam-se a subsidiar políticas, programas, projetos e atividades de controle, monitoramento, planejamento ambiental e econômico e combate ao desmatamento ilegal (SICAR, 2019) - Disponível em: www.car.gov.br 
totalizando $641,18 \mathrm{~km}^{2}$ (3,17\%) e Reserva Legal (proposta - encontra-se em processo de análise pelo órgão compentente) com 2.464,73 km² (12,19\%).

Neste contexto, constata-se que as alterações antrópicas promovem sérias consequências ao equilíbrio dinâmico do meio ambiente, motivo pelo qual justifica a necessidade de que se conheça as características ambientais dos locais onde se realizam significativas mudanças na paisagem (MESSIAS et al., 2012).

Este crescimento vem ocorrendo de forma isenta de grandes preocupações com os impactos ambientais que possam ser gerados em função da atividade em prática, uma vez que áreas com diferentes níveis de fragilidade ambiental, até mesmo em áreas que apresentam condições de restrições e/ou limitações de uso.

Constata-se principalmente a partir de 2000 na microrregião um contexto de pleno desenvolvimento da atividade pecuária com pastagens plantadas, porém a região começa a imprimir novas mudanças no uso da terra (SOARES, 2020).

As informações geográficas produzidas com 0 uso de geotecnologias mostram a transformação de áreas de pastagens em agricultura no segmento de commodities com sistema de irrigação por pivô central, aumentando de 112,5 km² em 2000 para 253,02 km² em 2018. Aumento gradual da agricultura de sequeiro que detinha 17,53 km² de área em 2000, aumentando para 225,65 km² em 2018 (SOARES, 2020).

Tais mudanças evidenciam novas tendências no modelo de desenvolvimento regional rompendo com a hegemonia da atividade de pecuária na região, passando a ter uma interação com outros sistemas, formando uma cadeia, tais como: atividades de confinamentos, construção de frigoríficos e desenvolvimento de uma agricultura comercial com o uso de sistema de manejo de irrigação por pivô central para cultivo de soja, feijão, milho, entre outros, tornando possível o aumento considerável da produção, além da possibilidade de ter mais de uma safra/ano, sinalizando indícios de novos usos e ocupação da terra e arranjos espaciais.

Afirmações estas corroboradas a partir de informações provenientes do levantamento de aparelhos de pivô central, realizado por Martins et al., (2019), onde a Microrregião Geográfica do Rio Vermelho - Goiás apresentou aumento de 12 para 249 pivôs centrais entre 1988 e 2018 respectivamente.

As mudanças verificadas dos diferentes usos e cobertura da terra são resultantes de fatores socioeconômicos, políticos e ambientais. Portanto, é essencial o entendimento de como esses fatores se correlacionam e promovem as 
transformações que ocorrem no uso e cobertura da terra, podendo condicionar impactos ao ambiente natural e nas atividades econômicas locais e regionais.

Para Ross (1994), a grande contribuição dos modelos de fragilidade ambiental é proporcionar uma maior agilidade no processo de tomada de decisões, servindo de subsídio para a gestão territorial de maneira planejada e sustentável, evitando problemas de ocupação desordenada.

Neste sentido, observa-se a eficácia dos resultados com a aplicação de geotecnologias na geração de geoinformações (processo de aquisição, tratamento, análise e modelagem de dados espaciais), subsidiando tomada de decisões com ênfase ao ordenamento e à gestão do território, permitindo que sejam realizados diagnóstico, prognósticos, estabelecer estratégias de planejamento para sugerir medidas de intervenções socioeconômicas e ambientais.

\section{CONSIDERAÇÕES FINAIS}

A unidade de paisagem consiste em informação de síntese servindo de subsídio para questões de planejamento e gestão do território seguindo procedimento técnico operacional com uma abordagem sistêmica.

A aplicação da metodologia de Ross (1994) na definição de áreas de fragilidade ambiental potencial e emergente na Microrregião Geográfica Rio Vermelho, contribui para o entendimento acerca do ambiente natural sofrer alterações em seu estado de equilíbrio dinâmico, como também de áreas classificadas como instáveis em que seu estado de equilíbrio foi alterado mediante ação humana.

As informações relativas ao uso e cobertura da terra e seu respectivo grau de proteção proporciona de forma imediata a identificação de áreas que apresentam características naturais estáveis sinalizando para estado de equilíbrio dinâmico, assim como áreas com instáveis em função da quebra do equilíbrio pela atividade do homem.

Com a aplicação do modelo é possível identificar zonas com maiores susceptibilidade a ocorrências de processos de degradação ambiental como erosões e as mais propícias às alterações da qualidade das águas de superfície, considerando os impactos advindos das atividades irrigadas na região, o que sugere um efetivo monitoramento da expansão deste sistema de uso. 
A região apresenta unidades de fragilidade que sugerem a existência de um suporte ambiental para expansão das atividades agropecuárias, porém é necessário: i) A adoção de sistemas de manejo que objetive a mitigação dos impactos ambientais gerados pelas atividades; ii) Obedecer às restrições de uso para evitar o surgimento de problemas de degradação ambiental; iii) Necessidade de reforçar a importância da atuação do poder público para um melhor planejamento e fiscalização de Áreas de Preservação Permanente (APP) e Reserva Legal (RL), as quais sofrem com ações de desmatamentos.

Os procedimentos técnicos-operacionais na aplicação da metodologia iniciam-se com a análise dos temas isoladamente, sendo atribuído uma hierarquização de diferentes pesos de fragilidade referente a cada variável ambiental (dissecação do relevo ou declividade/ pluviometria/solo/cobertura vegetal), por meio de multicritérios, sendo estabelecido uma associação e/ou combinação das condições ambientais na definição das unidades homogêneas.

A avaliação realizada para atribuição dos diferentes pesos a cada variável é dotada de subjetividade para determinar o quanto cada uma contribui para o estabelecimento do grau de fragilidade do ambiente, podendo levar a divergências, pois constituem em abstrações da realidade baseados em conceitos.

A aplicação da metodologia para a geração dos modelos de fragilidade potencial e fragilidade emergente, mostraram-se condizentes com as informações básicas utilizadas, fornecendo níveis básicos de diferenças entre os ambientes analisados e permitindo estabelecer uma padronização e auxiliando na tomada de decisão.

A produção cartográfica de síntese da microrregião, proporciona fazer uma leitura do conjunto de variáveis associadas, permitindo uma maior agilidade quanto ao processo de tomadas de decisões, subsidiando planos de gestão e planejamento territorial, evitando problemas de ocupação desordenada.

Deixa em evidência a importância da realização de estudos em escalas maiores visando a estruturação de planos de desenvolvimento sustentável para a região, sinalizando para necessidade de implementação de políticas públicas, requerendo uma atenção especial por parte do poder público e sociedade civil organizado. 


\section{REFERÊNCIAS}

ANA - Agência Nacional de Águas (Brasil). Rede Hidrometeorológica Nacional: Dados Pluviométricos, 2016.

ARCGIS. Versão 10.6.1®, [s. I.]. ESRI, 2018.

BERTONI, J. C.; LOMBARDI NETO, J. Conservação do solo. 4 ed. São Paulo - SP: Icone. 355 p., 1999.

CARVALHO, N.O. Hidrossedimentologia Prática. CPRM - Companhia de Pesquisa em Recursos Minerais - RJ: Brasil. 372 p., 1994.

COHEN, J. A coeficient of agreement for nominals scales. Journal of Educational and Measurement, Washington, v.20, n.1, p.37-46, 1960.

CONGALTON, R.G.A review of assessing the accuracy classifications of remotely sensed data. Remote Sensing Environment. v.37, p.35-46, 1991.

DONHA, A. G.; SOUZA, L. C. D. P.; SUGAMOSTO, M. L. Determinação da fragilidade ambiental utilizando técnicas de suporte à decisão e SIG. Revista Brasileira de

Engenharia Agrícola e Ambiental, v. 10, n. 1, p. 175-181, 2006.

DUARTE, M.M. et al. Visualização da fragilidade ambiental do município de Frederico Westphalen (RS) com a utilização de geotecnologias. Enciclopédia Biosfera, Centro Científico Conhecer, Goiânia, v.10, n.18; p.1263-1275, 2014.

FREITAS, M.W.D.; SANTOS, J.R. Zoneamento hierárquico da paisagem nos domínios da bacia do Rio Uruguai. Soc. \& Nat., Uberlândia, v. 26, n.2 p. 287-300, mai/ago.2014.

GUIMARAES, F.S. et al. Uma proposta para automatização do índice de dissecação do relevo. Revista Brasileira de Geomorfologia (Online), São Paulo, v.18, n.1, Jan/Mar, p.155-167, 2017.

IBGE - Instituto Brasileiro de Geografia e Estatística. Base Cartográfica - 2016. Disponível em: http://www.ibge.gov.br. Acesso em: 10 mar. 2017.

IBGE - Instituto Brasileiro de Geografia e Estatística. Censo Demográfico de 2010. Disponível em: http://www.ibge.gov.br. Acesso em: 15 abr. 2018.

IBGE - Instituto Brasileiro de Geografia e Estatística. Estimativa Demográfica-2018. Disponível em: http://www.ibge.gov.br. Acesso em: 15 abr. 2018.

KAWAKUBO, F. S. et al. Caracterização empírica da fragilidade ambiental utilizando geoprocessamento. In: Simpósio Brasileiro de Sensoriamento Remoto - SBSR, 12, Goiânia (GO). Anais... Goiânia. INPE, 2005, p. 16-21.

LATRUBESSE, E.; M. CARVALHO, T. M. Geomorfologia do Estado de Goiás e Distrito Federal. Secretaria de Industria e comércio. Superintendência de Geologia e mineração. Goiânia, 2006. 128p.

MARTINS, A.P; SOARES, C.B.R; MORAES, B. Mapeamento e análise da expansão da agricultura irrigada por pivô central na mesorregião Noroeste Goiano - Goiás - Brasil. In: XVIII Simpósio Brasileiro de Geografia Física Aplicada, v.1, 2019, Fortaleza. Anais... p. 112. 
MARTINELLI, M. Cartografia do turismo: que cartografia é essa? In: Lemos, I. G. org. Turismo: impactos socioambientais. São Paulo: Hucitec, 2001. p. 297-302.

MASSA, E.M.; ROSS, J.L.S. Aplicação de um modelo de fragilidade ambiental relevo-solo na Serra da Cantareira, bacia do Córrego do Bispo, São Paulo-SP. Revista do

Departamento de Geografia - USP, v. 24, p. 57-79, 2012.

MESSIAS, C.G. et al. Análise empírica de fragilidade ambiental utilizando técnica de geoprocessamento: O caso da área de influência da hidrelétrica do Funil - MG. Revista Geonorte, v. 2, n.4,p.112-125, 2012.

ROSS, J.L.S. Análise empírica da fragilidade dos ambientes naturais e antropizados. In: Revista do Departamento de Geografia. n.8, p.63-74, 1994.

SICAR - Sistema Nacional de Cadastro Ambiental Rural. Dados do Cadastro Ambiental Rural. Disponível em: <http://www.car.gov.br>. Acesso em 13 jan. 2019.

SIEG - Sistema Estadual de Estatística e Informações Geográficas de Goiás. Macrozae Macrozoneamento Agroecológico e Econômico do Estado de Goiás [2014]. Disponível em: <http://www.sieg.go.gov.br>. Acesso em: 05 abr. 2019.

SIEG - Sistema Estadual de Estatística e Informações Geográficas de Goiás.

Superintendência de Geologia e Mineração - SIC. Unidades geomorfológicas [2006].

Disponível em: < http://www.sieg.go.gov.br>. Acesso em: 02 abr. 2018.

SIEG - Sistema Estadual de Estatística e Informações Geográficas de Goiás.

Superintendência de Geologia e Mineração - SIC. Unidades geológicas [2008]. Disponível em: < http://www.sieg.go.gov.br>. Acesso em: 02 abr. 2018.

SIEG - Sistema Estadual de Estatística e Informações Geográficas de Goiás. Agência Ambiental. Determinação de áreas prioritárias para unidades de preservação Cons.Imagem/WWF - RADAMBRASIL [2005]. Disponível em: <http://www.sieg.go.gov.br>. Acesso em: 05 mai. 2018.

SOARES, C.B.R. Geotecnologias aplicadas na análise geoambiental da expansão da agricultura tecnificada na microrregião Rio Vermelho (GO): Fragiidades

Potencialidades.2020.192f. Dissertação (Mestrado em Geografia) Universidade Federal de Goiás, 2020.

SPÖRL, C. Análise da fragilidade ambiental relevo-solo com aplicação de três modelos alternativos nas altas bacias do Rio Jaguari-Mirim, Ribeirão do Quartel e Ribeirão da Prata. 2001. 165f. Dissertação (Mestrado em Geografia) Faculdade de Filosofia, Letras e Ciências Humanas - Universidade de São Paulo, São Paulo, 2001.

STORTO, C; COCATO, G.P. Análise de Fragilidade Ambiental a partir de Técnicas de Geoprocessamento: Área de Influência da Hidrelétrica de Mauá - PR. Revista Brasileira de Geografia Física, Pernambuco - PE, v. 11. n. 5. p.1694-1708, 2018.

SPRING. Versão 5.5.5®, Instituto Nacional de Pesquisa Espacial - INPE, 2018.

TRICART, J. Ecodinâmica. IBGE, Rio de Janeiro, 1977, 97p.

USGS - United States Geological Survey. Earth Explorer - Downloads de imagens Landsat, SRTM e Sentinel. Disponível em: < https://earthexplorer.usgs.gov/>. Acesso em: 20 mar. 2018. 


\section{NOTAS DE AUTOR}

\section{CONTRIBUIÇÃO DE AUTORIA}

Cleonice Batista Regis Soares - Concepção. Coleta de dados, Análise de dados, Elaboração do manuscrito, revisão e aprovação da versão final do trabalho.

Alécio Perini Martins - Concepção. Coleta de dados, Análise de dados, Elaboração do manuscrito, revisão e aprovação da versão final do trabalho

\section{FINANCIAMENTO}

O presente trabalho foi realizado com apoio da Coordenação de Aperfeiçoamento de Pessoal de Nível Superior Brasil (CAPES) - Código de Financiamento 001.

\section{CONSENTIMENTO DE USO DE IMAGEM}

Não se aplica

\section{APROVAÇÃO DE COMITÊ DE ÉTICA EM PESQUISA}

Não se aplica.

\section{CONFLITO DE INTERESSES}

Não se aplica

\section{LICENÇA DE USO}

Este artigo está licenciado sob a Licença Creative Commons CC-BY. Com essa licença você pode compartilhar, adaptar, criar para qualquer fim, desde que atribua a autoria da obra.

\section{HISTÓRICO}

Recebido em: 26-05-2020 Aprovado em: 02-07-2021 